\title{
NEST SITE USE AND BREEDING SUCCESS OF CHIMNEY SWIFTS IN ST. ADOLPHE, MB, 2007-2009
}

Barbara E. Stewart ${ }^{1}$, Robert E. A. Stewart ${ }^{2}$

1Sila Consultants, 1218 Marchand Rd., Howden, MB, R5A 1J6; E-mail: <sila@ highspeedcrow.ca>

2Department of Fisheries and Oceans, Freshwater Institute, 501 University Crescent, Winnipeg, MB, R3T 2N6; E-mail: <Robert.EA.Stewart@dfo-mpo.gc.ca>

Chimney swifts (Chaetura pelagica) are gregarious insectivores distinguished by a cigar-shaped body and long, tapered wings that extend well beyond the short, bristled rectrices (Fig. 1). ${ }^{1}$ After migrating north from their wintering grounds in the upper Amazon basin, ${ }^{1}$ chimney swifts arrive in southern Manitoba in mid- to late May. ${ }^{2}$ In this area, immature birds and non-breeding adults roost communally at night throughout the summer. ${ }^{1}$ Pairs of mature adults breed in sites that contain only one nest. ${ }^{1,3}$

The Manitoba Chimney Swift Initiative (MCSI) ${ }^{4}$ was formed in 2006 to address issues related to the reduced populations of chimney swifts in Manitoba ${ }^{2}$ and monitoring of chimney swift nest sites started in the spring of 2007 . The

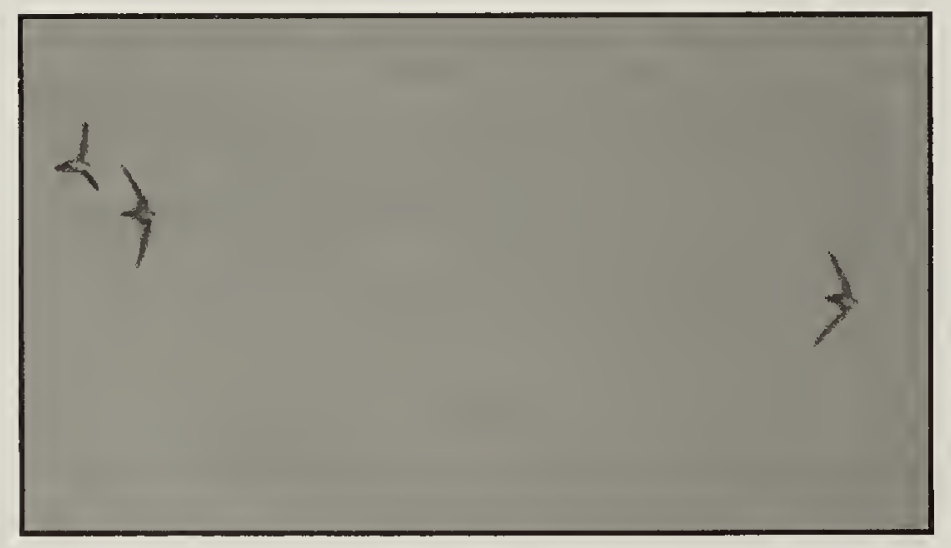

Figure 1. A trio of chimney swifts in flight. This photo illustrates the wing shape, the classic "cigar-shaped" body, and the "V" display of the bird at the far left.

Christian Artuso precipitous decline of chimney swift populations nationally has resulted in this species being listed in the spring of 2009 as 'Threatened' on Schedule 1 of the federal Species at Risk Act. ${ }^{1}$ Continued monitoring of the chimney swift population in Manitoba, ${ }^{4}$ elsewhere in Canada, ${ }^{5}$ and the United States ${ }^{6}$ is fundamental to the recovery potential of the species.

Historically, chimney swifts nested in natural tree cavities and perhaps some populations do so even now. ${ }^{1,2}$ Once European settlers removed old growth trees and established buildings, chimney swifts began nesting in chimneys. ${ }^{2}$ Nests are constructed of small twigs that are glued with sticky saliva to rough, interior surfaces, a considerable distance below a chimney rim.

Presently, chimney swifts typically breed in urban settings in eastern North America, from Texas and Florida through to southern Manitoba and southeastern Saskatchewan. 1,2,7 Near the northern periphery of their geographical distribution, breeding adults establish nests in old brick chimneys on four historic buildings along Main St. in St. Adolphe, MB $\left(49^{\circ}\right.$ 40' $27^{\prime \prime} \mathrm{N}, 97^{\circ} 6^{\prime} 38^{\prime \prime} \mathrm{W}$; $15 \mathrm{~km}$ south of Winnipeg). These nest sites were observed in 2007 to 2009 as part of the MCSI monitoring program. ${ }^{4}$ Nest site use 
by chimney swifts in Manitoba has not been monitored prior to this study.

Here we present the phenology of nest site use, behaviour of breeding adults, and breeding data collected for St. Adolphe nest sites in 2007 to 2009. We compare characteristics of nesting chimney swifts in Manitoba to southern locations in their range.

\section{Methods}

Five nest chimneys in St. Adolphe were identified in four different Main St. buildings situated in close proximity: Le Club Amical, Brodeur Bros. Ltd., St. Adolphe Catholic Church, and a private residence. In Le Club Amical, two brick chimneys that have not been used for heating for over 20 years are located in the two-storey structure, which was constructed in 1914. The chimneys are about $10 \mathrm{~m}$ apart in the southeast (SE) and northeast (NE) corners of the building. The SE Club Amical chimney was used as a nest site in 2009 only. Another nest site occupied for the first time in 2009 was in the two-storey Brodeur Bros. Ltd. car dealership (built in 1932), located $\sim 90 \mathrm{~m}$ north of Le Club Amical. The chimney is used seasonally for an oil burning furnace. The St. Adolphe Catholic Church chimney, built in 1913, is due north $(\sim 100 \mathrm{~m})$ of Brodeur Bros. The church has a high vaulted roof, and the chimney extends well above it. The church chimney has not been used for heating purposes for decades. The fifth nest site is in a 1918-constructed, private two-storey home on the west side of Main St., across from the church. The chimney, identified as the "Main St. chimney" has not been in service since 1995. It is about $95 \mathrm{~m}$ from the Brodeur Bros. chimney and $100 \mathrm{~m}$ away from the church chimney. All five nest chimneys are within $200 \mathrm{~m}$ of the Red River.

Each year, data collection spanned the entire time during which the chimney swifts were in St. Adolphe, from spring arrival through to late summer migration. Two observation periods were used: roosting hour and daytime. Roosting hour observations occurred from 30 min prior to sunset to $30 \mathrm{~min}$ after sunset; however, severe weather or heavy cloud cover and premature darkness resulted in some shorter observation periods. Daytime observations occurred any other time and were typically 60 min long but varied from 20 to $120 \mathrm{~min}$. Due to the location of nests deep within the chimneys, we could not observe nests, but observed entries and exits of birds from the chimney. Main St. and Brodeur Bros. chimneys have accessible cleanouts and were inspected to verify nesting activity at the end of the breeding season.

Roosting hour (at least weekly) and daytime observations (at least weekly, up to twice daily) always followed the same monitoring protocol. One or more chimneys were observed and the times of entries and exits were recorded to the nearest second. Entry and exit times yielded four intervals: 1) between consecutive entries; 2 ) between an entry and an exit, referred to as the "duration in the chimney", or the "turnaround time" for partner change-ups; 3 ) between consecutive exits; and 4) between an exit and an entry, referred to as the "betweenvisit" interval. The number of chimney swifts using a chimney was derived from the total number of entries versus exits, adjusted for consecutive use, e.g., entry followed by exit followed by entry $=2$ entries -1 exit $=$ at least 1 bird used the chimney; entry followed by entry followed by exit indicated that two birds used the chimney.

In 2008 and 2009, we also recorded the behaviour of individuals entering the chimneys and the group size of approaching or departing chimney 
Figure 2. Chimney swift in flight. The short tail and moulting indicate that this is an adult.

Christian Artuso

swifts. Trailing wing edges and notching observed on some occasions indicated moulting in adults (Fig. 2), ${ }^{3}$ whereas juveniles had complete, continuous wing edges. We identified fledglings by their low, relatively straight flight paths, and slow speed despite rapid wing beats. They generally had their tails lowered and fanned in a "flaps-down" position.

Five nesting stages were identified using our observations (see Results): 1) spring arrival; 2) start of nest building - characterized by exits from the chimney during the day, other than the first morning departure, and exits early in the roosting hour; 3) incubation; 4) feeding brooded and non-brooded young; and 5) fledging, which is followed by a pre-migratory phase and then migration. Previous, direct observations of chimney swift nests in artificial towers provided information on the duration of behaviours associated with various nesting stages in Texas ${ }^{3}$ and New York. ${ }^{8}$ We used those studies to retrospectively interpret our intervals and durations to identify transitions from one nesting stage to another. Stages of nesting activity were identified, and the phenology, viz. the dates on which these events were first observed, was recorded. We were unable to document ongoing nest building and egg laying.

Successful nesting was confirmed by the identification of fledglings, coupled with an increased number of roosting chimney swifts. Unsuccessful nesting was indicated initially by reduced activity in the chimney or abandonment of the site. A nest was considered to have failed after at least three consecutive observation periods, including one combined daytime/ roosting hour viewing, where no daytime activity was recorded.

\section{Results}

Approximately $350 \mathrm{~h}$ of observations were made. In 2007, observations began on 16 May when birds were already present, and ended on 22 August, $10 \mathrm{~d}$ after the last bird was observed. In 2008, observations began on 13 May and the first bird was seen on 17 May. The last bird was seen on 2 September and observations ceased on 4 September. In 2009, observations started 11 May and the first bird was seen on 21 May. Observations ended on 1 September, 5 $\mathrm{d}$ after the last bird was seen.

Eleven nesting attempts were recorded (Table 1) representing an occupancy rate of $73 \%$ over three seasons in the five chimneys. Due to the late date of first identifying the Main St. chimney in 2007 and early departures from the area that year, the outcome for that nest is unknown. Of the ten other nesting attempts, successful fledging was observed at four nest sites producing eight fledged juveniles (Table 1). All successful nests were started by a pair of chimney swifts before the end of May, and in no instance did helper birds assist in the nest building or rearing of young. Three or more consecutive entries/exits in the daytime would have indicated the presence of helpers.

Six of the ten nesting attempts failed (Table 1). In 2007, two adult chimney swifts were trapped in the church for approximately $5 \mathrm{~d}$. Although the birds were caught and released successfully 
Table 1. Phenology of chimney swift nest sites in St. Adolphe, Manitoba, 2007 to 2009. Unless otherwise indicated, arrival dates are based on when a pair arrived.

\begin{tabular}{|c|c|c|c|c|c|c|c|}
\hline Site & Arrival & Nest building & Incubation & $\begin{array}{l}\text { Feed } \\
\text { brooded } \\
\text { juveniles }\end{array}$ & $\begin{array}{l}\text { Feed non } \\
\text { brooded } \\
\text { juveniles }\end{array}$ & $\begin{array}{l}\text { Fledge } \\
\text { date (n } \\
\text { fledged) }\end{array}$ & Departure \\
\hline $\begin{array}{l}\text { NE } \\
\text { Club } \\
\text { Amical } \\
\text { Church }\end{array}$ & $\begin{array}{l}\text { May } 16 \\
\text { June } 3\end{array}$ & $\begin{array}{l}\text { May 16-27 } \\
\text { Failed Aug 3. Day }\end{array}$ & y use ended, $c$ & continued roc & July 7 & $\begin{array}{l}\text { July } 27- \\
\text { Aug } 1 \\
\text { (3) }\end{array}$ & Aug 13-19 \\
\hline Main St. & July 26 & & & & July 26 & Unknown & Ａug 15 \\
\hline $\begin{array}{l}\text { NE Club } \\
\text { Amical }\end{array}$ & May 14-17 & May $17-27$ & June 19 & July 9 & Failed July 13 & & Aug 13 \\
\hline Church & May 18 & May 27-29 & June 11 . & July 3 & July $10-13$ & $\begin{array}{l}\text { July } 31 \\
\text { (2) }\end{array}$ & Sept 2 \\
\hline$\stackrel{\sim}{N}$ Main St. & $\begin{array}{l}\text { May } 18 n=1 \\
\text { June } 17 n=1\end{array}$ & $\begin{array}{l}\text { May } 30 \\
\text { Failed July } 18-21\end{array}$ & June 30 & & & & $\begin{array}{l}\text { July 31- } \\
\text { Aug } 5\end{array}$ \\
\hline $\begin{array}{l}\text { SE Club } \\
\text { Amical }\end{array}$ & June 13-17 & June 17-19 & \multicolumn{3}{|c|}{$\begin{array}{l}\text { June } 30 \text {-July } 2 \\
\text { Failed July } 21 \text {. Day use ended, continued } \\
\text { roosting }\end{array}$} & & Aug 14 \\
\hline $\begin{array}{l}\text { NE Cub } \\
\text { Amical }\end{array}$ & May 19-26 & May 19-26 & June 9-13 & July 2-8 & July 16 & $\begin{array}{l}\text { Aug } 4 \\
\text { (2) }\end{array}$ & Aug 11 \\
\hline $\begin{array}{l}\text { Brodeur } \\
\text { Bros. }\end{array}$ & June 19 & ～June 19 & \multicolumn{3}{|c|}{$\begin{array}{l}\text { July } 10-16 \text {. } \\
\text { Failed July } 26 \text {. Day use ended, continued } \\
\text { roosting }\end{array}$} & & Aug 3-6 \\
\hline Church & May 11-21 & $\begin{array}{l}\text { May 29- } \\
\text { June } 2\end{array}$ & June 3-7 & $\begin{array}{l}\text { June 26- } \\
\text { July } 13\end{array}$ & July $18-20$ & $\begin{array}{l}\text { Aug } 1 \\
\text { (1) }\end{array}$ & Aug 28 \\
\hline Main St. & $\begin{array}{l}\text { May } 21 n=1 \\
\text { June } 2-7 n=1\end{array}$ & May 24 & $\begin{array}{l}\text { June 30- } \\
\text { July } 3\end{array}$ & $\begin{array}{l}\text { July } 17- \\
19\end{array}$ & \multicolumn{2}{|l|}{$\begin{array}{l}\text { July 24-25 } \\
\text { Failed July 29-30 }\end{array}$} & July 31 \\
\hline
\end{tabular}

(J. Brodeur, M. Lagasse, G. Michaud, pers. comm.), this interruption probably contributed to the nesting failure. After their release around 11 July, chimney swifts were not active in the church until 18 July, when daytime activity resembling nest building and incubation started. However, daytime use ceased, without fledglings being observed, on 3 August.
The NE Club Amical 2008 nest that was initiated in May failed in July following an intense rain storm. The Main St. home owners verified that the other 2008 failure did not involve nest slippage. Although these birds appeared to be incubating, the nest was empty, and no eggs or bodies were recovered from the cleanout; thus, the cause of abandonment in mid-July is 


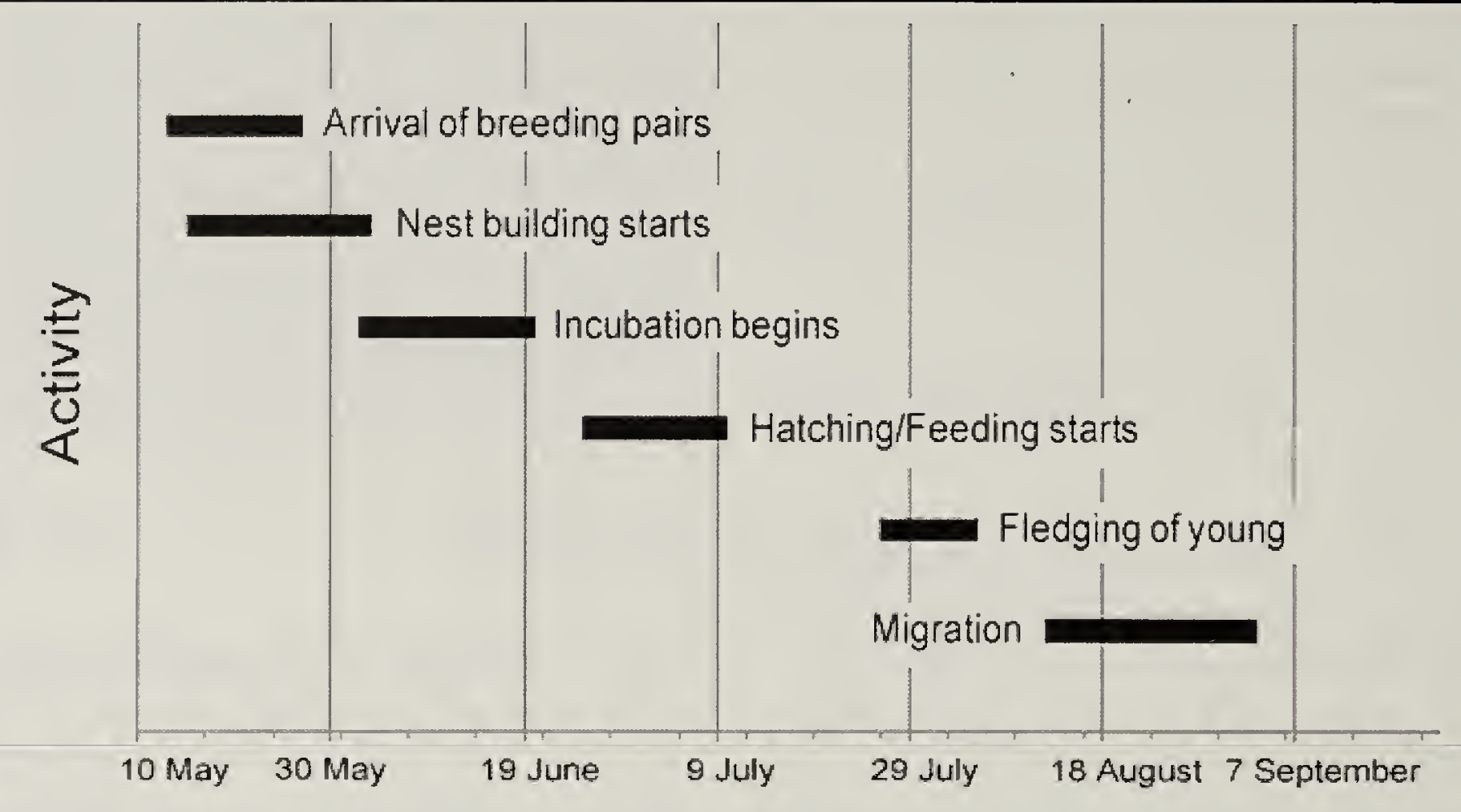

Date

Figure 3. Range of dates for the first observation of different nesting stages for pairs of chimney swifts arriving at St. Adolphe, Manitoba, in May (2007 to 2009).

unknown. In 2009, abrupt cessation of daytime use at Brodeur Bros. indicated that the nest had been abandoned, although the adults continued to roost there. Intact eggs, but no nest, were found in the cleanout at the bottom of the chimney at the end of August. Similarly, debris and remains of dead young at the bottom of the Main St. chimney in August 2009 indicated that not only had the nest fallen off the chimney, probably killing a 10- to 11-day-old juvenile but another juvenile, $\sim 2 \mathrm{~d}$ old, had fallen or been ejected previously from the nest. Also, two chimney swifts left the SE Club Amical chimney and were trapped in a closet around 17 June 2009. One bird died and one was released. Subsequently, an adult pair continued with a nesting attempt that failed, likely at the incubation stage.

Two patterns of adult behaviour associated with nest loss were evident. The first pattern involved a gradual decline of daytime use then a relocation of the adults to a different roost. This pattern appeared to be associated with the loss of juveniles (e.g., Main St. nest in 2009).
The other pattern was characterized by the abrupt abandonment of the nest site during the daytime, although adults continued to roost there at night.

The phenology of successful nest sites was used to identify the seasonal pattern of the various nesting stages (Table 1 , Fig. 3).

1. Arrival. Pairs typically entered the chimney once, within a few minutes of each other, during the roosting hour to rest for the night.

2. Nest building. Pairs of chimney swifts entered and exited the chimney during the roosting hour or slightly before. Daytime visits also occurred. Chimney swifts did not always travel in pairs but often entered or exited the chimney individually. The duration in the chimney and the between-visit interval both varied considerably, from 1 to $70 \mathrm{~min}$ and from 1 to $50 \mathrm{~min}$, respectively.

3. Incubation. The adults took turns on the nest during incubation, ${ }^{3}$ and in St. Adolphe, partner exchanges were 
quick. Turnaround times were often less than 30 seconds, and one or two change-ups per hour were typical. Usually, one attending adult was in the chimney, but there were short unattended periods, often around dusk.

4. a) Feeding brooded juveniles. After a feeding, an adult Chimney Swift will brood or cover the nestlings to keep them warm. ${ }^{3}$ In St. Adolphe, nest site use became more active at this stage. Two entries and two exits within an hour, with quick adult turnaround times of $\sim 1 \mathrm{~min}$, were typical in early July.

b) Feeding non-brooded juveniles. Juveniles do not require brooding by their parents after 6 to $7 \mathrm{~d}$ of age. ${ }^{3}$ Adults may simply move to the wall beside the nest and not leave the chimney, ${ }^{8}$ or both adults may forage concurrently to meet the increasing energetic demands of the juveniles. ${ }^{3}$ An unattended chimney, indicated by consecutive entries or exits, was a sign of the non-brooding phase. In St. Adolphe, the time young were unattended increased as the juveniles aged (e.g., from 2 min with $\sim 7$-dayold chicks to 16 min with $\sim 26$-day-old chicks). However, the best indicator of advancing juvenile age was the increased frequency of entries/exits, typically four entries and four exits per hour. The between-visit intervals were variable, 1 to $17 \mathrm{~min}$, as the adult chimney swifts sometimes used the chimney in bursts separated by lulls.

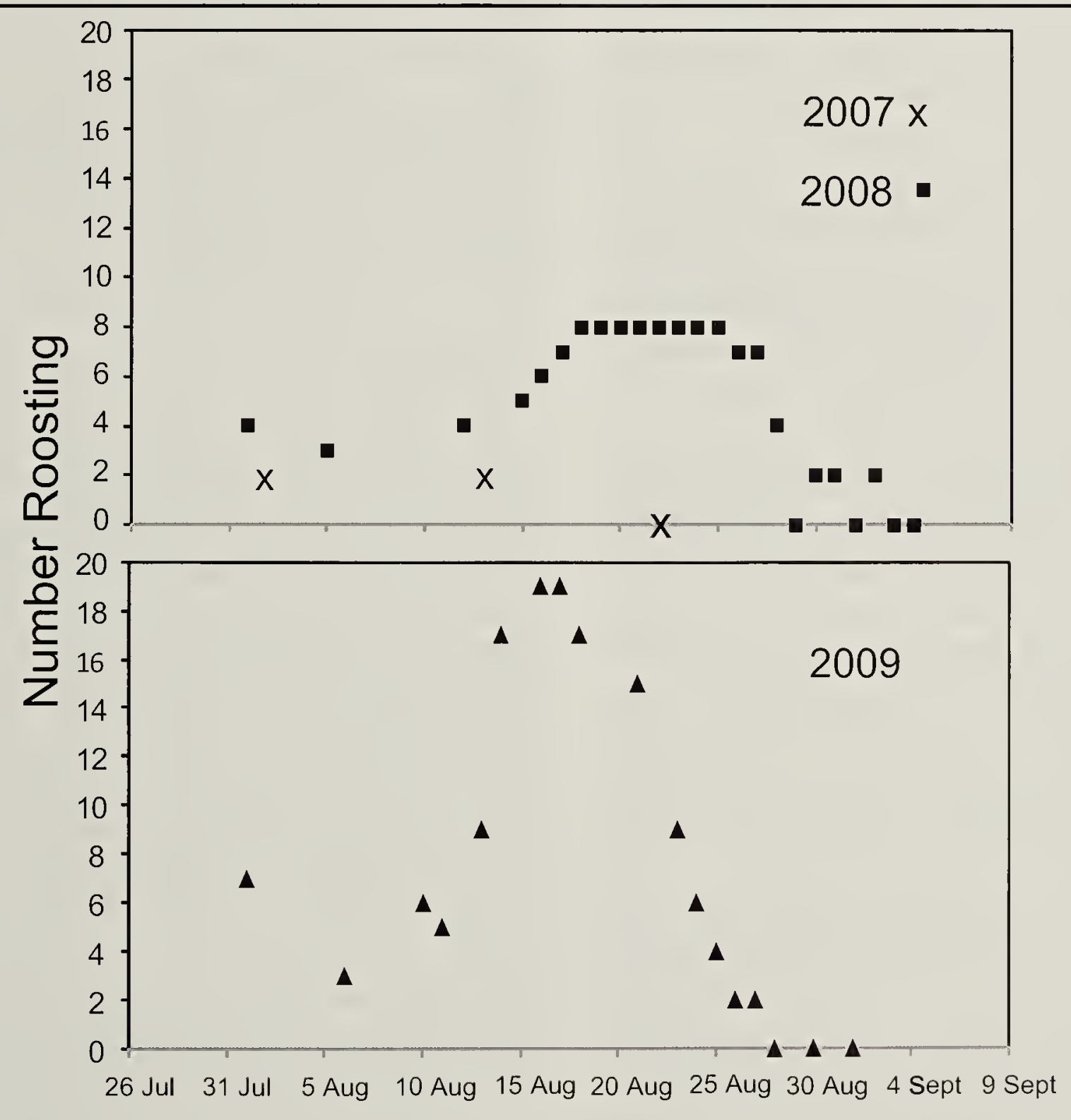

\section{Date}

Figure 4. Total counts of chimney swifts roosting at a church in St. Adolphe, Manitoba, in August and September 2007 to 2009. 
5. Fledging. Fledging was determined when juveniles were identified flying for the first time. In some cases, the adults made many entries and exits just before the young fledged e.g., eight entries and eight exits in $1 \mathrm{~h}$ with turnaround times of several minutes.

After juveniles started flying, the number of chimney swifts seen together in the air was at a maximum (Fig. 4) and they were highly vocal. Groups of juveniles and their attending adults flew at low levels in the corridor between Club Amical and the church and over the adjacent fields to the east. Juveniles entered chimneys to rest during the day, using their own natal chimney and other local chimneys.

Daytime entry/exit patterns were variable during the fledging period (e.g., NE Club Amical; fledging day 4 August 2009; 13 entries, 11 exits; 08:47 to 10:02 h). Not only were fledglings moving among chimneys, but both adults, which still feed the young at this stage, ${ }^{3}$ entered and exited the natal chimney during the day. Also, some adults that were unsuccessful in their nesting attempt relocated.

- Pre-migratory phase. Local birds moved among chimneys during the day and roosting hour. Local movements all took place by 15 August. At this time, group sizes seen in the air were smaller as the birds ranged farther away from the nest site area to feed (Fig. 4). Consequently, there was less daytime use of chimneys in the 7 to 10 $\mathrm{d}$ after fledging compared to earlier stages.

- Migratory phase. When the total known population of local adult and juvenile chimney swifts was exceeded by roosting birds, it was obvious that some migrants had arrived. Roosting hour counts at the church indicated aggregations of local and migrant chimney swifts (Fig. 4). Chimney swifts entered the chimney singly or in small groups, during or slightly before, the roosting hour. We interpreted repeated flyovers with veer-offs preceding a halting, foot-first entry as a migrant's first use of an unfamiliar chimney. Late in the season, exits from the chimney were rare and usually were followed by a quick re-entry. After the numbers of roosting chimney swifts peaked, the dispersal of migrating birds eventually reduced roosting counts to zero (Fig. 4).

Migratory patterns varied among years (Fig. 4). In 2007, all birds appeared to disperse by mid-August without forming any local groups. In 2008, a small, local roosting group assembled at the church when the other nest sites were abandoned; then migration started as reflected in the decline of roosting birds (Fig. 4). In 2009, local chimney swifts congregated to roost at the church and were joined by migratory birds. Peak numbers of chimney swifts in 2009 exceeded those of 2008.

\section{Discussion}

Chimney swifts continue to construct nests well into the egg-laying and incubation stages. In general, the birds take an average of $18 \mathrm{~d}$ and up to $30 \mathrm{~d}$ to build a nest, ${ }^{7}$ but egg laying may begin as early as 3 to $7 \mathrm{~d}$ into the construction period. ${ }^{3,7}$ Incubation is shared by both adults and starts when the second-last egg is laid; $1,3,7$ however, nest building continues until the first egg hatches, ${ }^{3,7}$ Once the first juvenile emerges, all nest building stops and adults tend their young. ${ }^{3}$ Toward the southern edge of the breeding range near Austin, Texas $\left(30^{\circ}\right.$ $16^{\prime} 1^{\prime \prime} \mathrm{N} 97^{\circ} 44^{\prime} 35^{\prime \prime} \mathrm{W}$ ), incubation lasts 18 to $21 \mathrm{~d}$, feeding brooded juveniles lasts for 6 to $7 \mathrm{~d}$ after hatching, and feeding nonbrooded juveniles then extends another 21 to $24 \mathrm{~d}$ until the young are 28 to $30 \mathrm{~d}$ of age. ${ }^{3}$ Therefore, there is normal variation in the time from start of incubating eggs 
to fledging of young (minimally $18+28$ $=46 \mathrm{~d}$ to, maximally, $21+30=51 \mathrm{~d}$ ). Chimney swifts nesting in New York in 2009 had similar durations of incubation and feeding. ${ }^{8}$ Previously, there have been no comparable data on the duration of nesting stages, and intervals between them, for chimney swifts in Manitoba. This study adds to the three nest records on file for Manitoba. ${ }^{2}$

Chimney swifts from various geographic locations appear to have similar durations of incubation and feeding young. However, differences exist for the intervals between the time of arrival, the onset of nest building, and the start of incubation in various locations. In New York, there was a lag of approximately 4 wk between arrival and the start of nest building, plus an interval of 5 wk between the onset of nest building and incubation. ${ }^{8}$ Similar time lags are inferred for Texas (arrive mid-March, nest May through August, depart mid- to late October). ${ }^{3}$ In contrast, nest building in Manitoba was initiated within $1 \mathrm{wk}$ of arrival at the nest site; the interval between the start of nest building and incubation was approximately 1 to 3 wk. Chimney swifts in Texas may raise two broods per season, ${ }^{3}$ but in New York ${ }^{8}$ and Manitoba, one brood is raised. ${ }^{1}{ }^{1, \text { this }}$ study Eight weeks were required for nest building through to fledging. An additional 2 wk were required before migratory movements began in mid-August. The variation in patterns of daily nest use may reflect variance in precipitation and temperature in addition to the variation due to developmental stages of the juveniles. ${ }^{9-11}$

Clutch sizes of two to seven are reported for Austin, Texas, ${ }^{3}$ while three to five are typical in Glenham, New York, ${ }^{8}$ and Macomb, Illinois $\left(40^{\circ} 27^{\prime} 33^{\prime \prime} \mathrm{N} 90^{\circ}\right.$ $40^{\prime} 18^{\prime \prime}$ W)..$^{12}$ At St. Adolphe, Manitoba, fledgling counts are a proxy for clutch size, with the number of fledglings per nest observed to range from one to three. However, four intact eggs were recovered from the Brodeur Bros. chimney in 2009, suggesting that clutch size might be higher than the number of fledglings observed.

Abandonment seemed indicative of nest loss at earlier nesting stages. For example, intact eggs (Brodeur Bros. 2009) and an empty nest (Main St. 2008) were found, suggesting that these nests failed during incubation or before egg laying, respectively. Hatching to fledging takes about $1 \mathrm{mo}$, and all successful fledging occurred between 27 July and 4 August in St. Adolphe, so eggs being incubated in mid-July are severely time-constrained. In two cases, a chimney containing nonbrooded young was scrutinized ${ }^{3}$ intensely the evening preceding the sudden abandonment of the late nests.

Daytime monitoring is essential to distinguish roosts from nest sites. Early in the breeding season, pairs of chimney swifts establish their territory in chimneys. ${ }^{3}$ Late-arriving birds attempting to roost at a nest site may be displaced by the resident pair. The baseline number of adults (breeding pair + helpers) ${ }^{3}$ tending a nest must be established prior to fledging to calculate the number of juveniles fledged. When juvenile chimney swifts are identified during the day, roosting hour observations made the same night will identify an increase in the number of roosting birds. Fledglings may enter the chimney before the roosting hour to rest for the night, so a longer period of observation prior to sunset is advantageous.

\section{Summary}

Not all chimney sites in St. Adolphe, $M B$, were used by chimney swifts every year. Only one nesting attempt was made per season per pair, and the number of fledged birds was $\leq 3$. Nest site use 
and breeding success differed in some respects compared to southern locations in the chimney swifts' breeding range. While the duration of incubation and feeding stages in St. Adolphe appeared consistent with birds at the southern end of the distribution, the time between arrival and the onset of nest building, then incubation, was considerably shorter in Manitoba. There was a high rate of nest failure in chimney swifts breeding at the northern periphery of the distribution. Also, the constraints involved for chimney swifts breeding in Manitoba, including such factors as time, rates of nest building, feeding strategies, and weather, warrant investigation.

\section{Acknowledgements}

We are indebted to the community of St. Adolphe, MB, for their considerable support of this study. Sincere thanks are extended to: the avian landlords - A. and S. Leclerc, Fr. G. Michaud on behalf of the Paroisse St. Adolphe Catholic Church, H. Brodeur of Brodeur Bros. Ltd, and M. Lagasse on behalf of Club Amical; the RM of Ritchot - Mayor R. Stefaniuk, CAO F. May, and Councillor V. Rutherford; observer - A. Lagasse; and the Chimney Swift rescue team - J. Brodeur, M. Lagasse, and Fr. G. Michaud. Much appreciated assistance, for wide ranging tasks, has been provided by devoted family members, the MCSI Steering Committee, collaborators, and volunteers at large: D. Stewart, R. Stewart; C. Artuso, R. Austin, R. Bazin, L. Cocks, K. De Smet, L. Jansson, V. Kanya, F. Machovec, L. McDonald, A. Mickey, G. Ogilvie, R. Porteous, M. Quigley, N. Schmidt, J. Whitelaw; J. Klapecki, R. Mooi, B. Redekop; R. Clarke, R. Cocks, E. Gong, J. Hamilton, S. Hnytka, C. Little, M. Lumsden, J. Machovec, J. Ogilvie, R. Pereira, K. Quigley, and A. Westra. This manuscript benefitted from thoughtful reviews of early drafts provided by $C$. Artuso, R. Bazin, L. Cocks, K. De Smet,
M. Quigley, and Blue Jay editors and anonymous reviewers. We acknowledge G. and P. Kyle, Austin, Texas, for their long standing devotion to chimney swift conservation and the hosts of the chimney swift nestcam in Glenham, NY, for providing live links to the hidden life inside the chimneys.

1. Government of Canada (2009) Species At Risk Public Registry. Species Profile: Chimney Swift. <http://www.sararegistry.gc.ca/species/ speciesDetails_e.cfm?sid=951>

2. Manitoba Naturalists Society, Manitoba Avian Research Committee (2003) The Birds of Manitoba. Friesens Printers, Altona, MB.

3. Kyle GZ, Kyle PD (2005) Chimney Swifts. America's Mysterious Birds above the Fireplace. Texas A \& M University, College Station, TX.

4. Manitoba Chimney Swift Initiative (2009) <http:// www.manitobanature.ca/CHSW.html>

5. Bird Studies Canada (2009) <http://www.bsc-eoc. org/birdmon/chsw/about.jsp>

6. Driftwood Wildlife Association (2009) A Swift Night Out. <http://www.chimneyswifts.org/>

7. Cink CL, Collins CT (2002) Chimney swift (Chaetura pelagica). In: Poole A, Gill F (eds) The Birds of North America, No. 646. The Birds of North America, Inc., Philadelphia, PA.

8. Cornell Lab of Ornithology (2009) Chimney Swift nestcam. <http://watch.birds.cornell.edu/nestcams/ camera/view?cameralD $=\mathrm{C} 100060>$

9. CBC News Archives (2009) 31 July: Lousy Winnipeg weather sets record. <http://www.cbc. $\mathrm{ca} / \mathrm{canada} / \mathrm{manitoba/story} / 2009 / 07 / 31 / \mathrm{mb}$-wretchedweather-winnipeg.html>

10. Environment Canada (2009) Daily data report for July 2009. <http://www.climate.weatheroffice. ec.gc.ca/climateData/dailydata_e.html?timeframe= 2\&Prov $=X X \&$ Station $I D=47407 \&$ Year $=2009 \&$ Month $=7 \&$ Day $=1>$

11. Winnipeg Free Press (2009) 31 August: Weather record leaves us cold. <http://www. winnipegfreepress. com/breakingnews/Weather-record-leaves-us-cold56349932.html>

12. Zammuto RM, Franks EC, Preston CR (1981) Factors associated with the interval between feeding visits in brood-rearing chimney swifts. Journal of Field Ornithology 52:134-139. 